\title{
Title: The Importance of using Alkaline Ionomer Binders for Screening Electrocatalysts in Alkaline Electrolyte
}

\author{
Author Names: Rhodri Jervis ${ }^{1}$, Noramalina Mansor ${ }^{1}$, Ana Jorge Sobrido ${ }^{2}$, Simon Jones ${ }^{1}$, \\ Christopher Gibbs ${ }^{1}$, Tobias P. Neville ${ }^{1}$, Jason Millichamp ${ }^{1}$, Paul R. Shearing ${ }^{1}$, Daniel J. L. \\ Brett $^{1 \mathrm{z}}$
}

Affiliation(s): ${ }^{1}$ Electrochemical Innovation Lab, Dept. Chemical Engineering, University College London, London, WC1E 6BT, UK

2. Materials Research Institute, School of Engineering and Materials Science, Queen Mary University of London, London, E1 4NS, UK.

zd.brett@ucl.ac.uk

\begin{abstract}
Text: Many electrochemical studies exist using the acidic ionomer Nafion ${ }^{\circledR}$ as a binder in the ink formulation when operating in high $\mathrm{pH}$ systems. However, Nafion ${ }^{\circledR}$ acts as an ionic insulator for $\mathrm{OH}^{-}$, and for reactions such as the hydrogen oxidation reaction, the transport of $\mathrm{OH}^{-}$to the catalyst surface is of utmost importance when elucidating the performance of a catalyst. This work demonstrates that when using an alkaline polymer binder in the ink, the apparent activity of a commercially synthesised $\mathrm{Pt} / \mathrm{C}$ catalyst is increased due to a lower diffusion resistance for the reaction. In order to obtain accurate values for kinetic data in alkaline media, the use of the acidic binder should be avoided.
\end{abstract}

\section{Introduction}

Fuel cells are seen as a transformative technology that could facilitate the move away from the reliance on fossil fuels, particularly for automotive applications; however, they presently suffer from cost and durability issues. One route to cost reduction in fuel cells is the alkaline anion exchange membrane fuel cell (AAEM FC) [1-15]. As opposed to the more established proton exchange membrane fuel cell (PEMFC) that employs a proton conducting polymer as the electrolyte, AAEMs allow conduction of hydroxide anions through a polymer electrolyte. The oxygen reduction reaction (ORR) at the cathode of the fuel cell has superior kinetics in alkaline media compared with the sluggish reaction in acid, thus allowing the use of 
non-noble metal catalysts in place of the Pt-based materials most commonly used in PEM fuel cells [16-24]. However, the hydrogen oxidation reaction (HOR), which is extremely facile in acid and allows ultra-low loadings of catalyst on the anode of PEMFCs, is an order of magnitude slower in alkaline than in acid [20, 25, 26]. Catalyst development for the anode is an often overlooked aspect of PEMFC research, but is a vital area of improvement if AAEM fuel cells are to emerge as a valid alternative to the state-of-the-art PEMFCs [12, 27]. One of the most widely used tools for assessing the activity of fuel cell catalysts is the rotating disk electrode (RDE), wherein an electrode is created from deposition of a catalyst-containing ink on a glassy carbon surface and rotated in an electrolyte solution containing the dissolved gas of interest (hydrogen for the HOR) [28-34]. Varying the rotation rate of the electrode changes the thickness of the static hydrodynamic diffusion-layer at the surface, and thus the diffusion rate of the reactant to the catalyst. This allows separation of the kinetic and diffusion controlled currents via the Koutecky-Levich equation [35] and, therefore, calculation of the exchange current density, a key indicator of the performance of a catalyst [30, 34-37]. Many experimental factors can mask the true kinetic performance of a catalyst in RDE studies, and so creation of a high quality and reproducible electrode that best represents the conditions experienced in the fuel cell environment is of paramount importance $[28,38,39]$.

Although the proton-conducting polymers act as a barrier to diffusion of hydroxide in alkaline media, many of the studies in literature employ $\mathrm{Nafion}^{\circledR}$, or similar acidic ionomers, in the electrodes [40-50]. A small number of studies exist where the electrode is made from an ink containing no binder $[20,25,51]$ or an alkaline anion ionomer binder [52-54]; however, the effect of the lack of ionomer is not generally commented upon. To the authors' knowledge, only one study has compared the use of an alkaline binder to that of Nafion ${ }^{\circledR}$, but the focus of this work was in determining the blocking effect of organic cations and comparing an in-house alkaline ionomer with a commercial one (AS-4, Tokuyama corporation) [55]. The detrimental effect of $\mathrm{Nafion}^{\circledR}$ on the HOR in alkaline is shown, but not emphasised and many studies have continued to use Nafion ${ }^{\circledR}$ as a binder since. The results presented in this paper will show the importance of using a hydroxide conducting ionomer in the ink formulation, both as a binder and as a way of more closely mimicking the catalyst 
layer in an operating AAEM fuel cell, and highlight the need to move away from Nafion ${ }^{\circledR}$ as a binder in alkaline RDE studies.

\section{Experimental}

A commercial Pt/C catalyst (Alfa Aesar, $39.25 \%$ wt) was used to create two inks; one containing a proton conducting ionomer $\left(\mathrm{Nafion}^{\circledR}\right)$ and one a hydroxide conducting ionomer (AS-4, Tokuyama corporation), denoted $\mathrm{Pt} / \mathrm{C}-\mathrm{H}^{+}$and $\mathrm{Pt} / \mathrm{C}-\mathrm{OH}^{-}$, respectively. Though the cationic ionomer Nafion ${ }^{\circledR}$ is in its proton form as received and when the ink is made, it will ion exchange to the potassium form when submerged in the $\mathrm{KOH}_{(\text {aq) }}$ electrolyte and therefore the notation $\mathrm{Pt} / \mathrm{C}-\mathrm{H}^{+}$is not meant to represent the form of the electrode during experiments, but simply to differentiate this electrode from the one containing the anion exchange polymer ionomer. $7 \mathrm{mg}$ of catalyst was mixed with a volume of ionomer solution such that the mass of solid ionomer is $80 \%$ of that of the carbon in the catalyst, and $1 \mathrm{ml}$ of acetone followed by $9 \mathrm{ml}$ of propanol was added to produce an ink with a density of around $1.4 \mathrm{mg}_{\mathrm{Pt}} \mathrm{ml}^{-1}$. The manufacturer provided density of the ionomer solutions is similar, and stated to be $0.94 \mathrm{~g} / \mathrm{ml}$ (AS-4) and $0.924 \mathrm{~g} / \mathrm{ml}\left(\right.$ Nafion $\left.^{\circledR}\right)$, and both electrodes (to two decimal places) have the same estimated thickness of $0.45 \mu \mathrm{m}$. The inks were sonicated for ca. two hours then deposited with a micropipette onto a polished glassy carbon electrode, creating a metal loading of $35 \mu \mathrm{g} \mathrm{cm}^{-2}$. In order to characterise the quality of the electrode layer, the electrodes were imaged in an SEM (EVO MA 10, Carl Zeiss, USA).

A PTFE electrochemical cell (manufactured to the specifications outlined by Mayrhofer et al. [56]) was filled with $0.1 \mathrm{M} \mathrm{KOH}_{(\mathrm{aq})}$ and deaerated by bubbling nitrogen for 20 minutes before taking cyclic voltammograms (CVs). Subsequently, the electrolyte was saturated with hydrogen gas for one hour before linear sweep voltammetry (LSV) at rotation rates of 400, 600, 900, 1200 and $1600 \mathrm{rpm}$ to measure the HOR kinetics. A reversible hydrogen electrode (RHE, Gaskatel) was used as a reference and Pt mesh as the counter electrode.

Electrochemical impedance spectroscopy (EIS) was carried out in potentiostatic mode at $0.025 \mathrm{~V}$ vs RHE and $1600 \mathrm{rpm}$ in a $\mathrm{H}_{2}$ saturated electrolyte over a frequency range of $0.1 \mathrm{~Hz}$ to $100 \mathrm{kHz}$ with an amplitude of $10 \mathrm{mV}$. ZView software (Scribner) was used to model and fit the equivalent circuits. 
Though anion exchange membranes can suffer degradation at elevated temperatures in the presence of hydroxide [57], Nafion ${ }^{\circledR}$ shows good stability at high $\mathrm{pH}$ [58]. All experiments were conducted in under two hours and at room temperature to eliminate the effect of degradation of the ionomer.

\section{Results and Discussion}

Figure 1 shows SEM images of the electrode layers deposited on the RDE electrodes. Though there are areas of inhomogeneity for both electrodes, in general there are large areas of agglomerated catalyst for the $\mathrm{Pt} / \mathrm{C}-\mathrm{OH}^{-}$electrode, confirming the general trend that has been observed by the authors that the $\mathrm{Pt} / \mathrm{C}-\mathrm{OH}^{-}$electrodes consistently produced a poorer electrode layer than the $\mathrm{Pt} / \mathrm{C}-\mathrm{H}^{+}$electrodes, with visible areas of agglomeration to the eye. The higher magnified views (Figure 1c and d) show the typical form of the structure of inhomogeneity in the electrodes, with $\mathrm{Pt} / \mathrm{C}-\mathrm{H}^{+}$showing a porous 'wave-like' patterning and $\mathrm{Pt} / \mathrm{C}-\mathrm{OH}^{-}$with large amounts of catalyst material agglomerating in clusters.

TEM, not shown here, indicated no discernible difference to the catalyst structure on addition of either ionomer as a binder, and so it can be assumed that any differences in performance of the $\mathrm{Pt} / \mathrm{C}-\mathrm{H}^{+}$and $\mathrm{Pt} / \mathrm{C}-\mathrm{OH}^{-}$electrodes cannot be due to the $\mathrm{Pt} / \mathrm{C}$ catalyst structure being fundamentally affected by the ionomer.

Figure 2a shows the $\mathrm{CVs}$ of $\mathrm{Pt} / \mathrm{C}$ in $0.1 \mathrm{M} \mathrm{KOH}_{(\mathrm{aq})}$ for both the Nafion ${ }^{\circledR}$ containing electrode (grey) and the alkaline ionomer containing electrode (black). Both electrodes display the characteristic hydrogen adsorption/desorption peaks at low potentials and oxide formation/removal peaks at higher potentials.

The hydrogen desorption area, after subtraction of the double-layer capacitance, was used to calculate the electrochemical surface-area (ECSA) of each electrode, in accordance with a common method in the literature [59]. In order to minimise the human error involved, this process was repeated five times for each electrode and yielded average ECSAs of $33.7 \mathrm{~m}^{2} \mathrm{~g}^{-1}$ ( $\sigma$ 1.9) and $29.7 \mathrm{~m}^{2} \mathrm{~g}^{-1}(\sigma=2.4)$ for the $\mathrm{Pt} / \mathrm{C}-\mathrm{OH}^{-}$and $\mathrm{Pt} / \mathrm{C}-\mathrm{H}^{+}$electrodes, respectively. Given that both electrodes were made using the same catalyst, this suggests that the acidic polymer has a blocking effect on the surface of the catalyst, giving artificially lower ECSA than when 
combined with an alkaline ionomer in alkaline electrolyte.

Figure $2 \mathrm{~b}$ shows the LSVs for HOR on the two electrodes at $1600 \mathrm{rpm}$. Control of the rotation rate allows separation of the kinetic and diffusion controlled contributions to the overall current by controlling the thickness of the Levich layer. The characteristic shape of the LSV curves shows the reaction becoming diffusion limited at higher polarisations, with the limiting currents being proportional to the inverse square root of rotation rate [60]. The limiting current is also dependent on the number of available reaction sites, which is why the $\mathrm{Pt} / \mathrm{C}-\mathrm{OH}^{-}$electrode, suffering from the aforementioned agglomeration issues, plateaus at a lower current; for the same catalyst loading and geometric area, the agglomeration means fewer of the reaction sites are available for $\mathrm{Pt} / \mathrm{C}-\mathrm{OH}^{-}$than for $\mathrm{Pt} / \mathrm{C}-\mathrm{H}^{+}$.

The exact mechanism of HOR on Pt remains under debate; however, it is thought to proceed under a combination of the Tafel/Heyrovsky and Volmer reactions [20]. As $\mathrm{OH}^{-}$is a reactant in these mechanisms, the ability for hydroxide to access the triple phase boundary is important for the rate of reaction. Ionomer coats the surface of the catalyst in these electrodes and thus mass transport of hydroxide through the ionomer is required for reaction - mass transport that is separate to the rotation rate dependant mass transport of $\mathrm{H}_{2}$ through the Levich layer. Because of this, the two electrodes display different reactivity for the HOR, despite consisting of the same catalyst under the same rotation rate. At lower polarisation the gradient of the curve is steeper for $\mathrm{Pt} / \mathrm{C}-\mathrm{OH}^{-}$, indicating a better kinetic performance. This is due to the greater restriction of mass transport of hydroxide ions through the acidic ionomer, masking the inherent activity of the $\mathrm{Pt} / \mathrm{C}$ catalyst.

In order to extract the kinetic currents from the LSVs, data are collected at multiple rotation rates for each electrode (Figure 3a, b) and the Koutecky-Levich equation (Equation 1) is used to generate Koutecky-Levich plots of $\frac{1}{i}$ vs $\frac{1}{\omega^{1 / 2}}$ at five potentials between $0.025-0.125 \mathrm{~V}$ (Figure 3c, d).

$$
\frac{1}{i}=\frac{1}{i_{k}}+\frac{1}{i_{d}}=\frac{1}{i_{k}}+\frac{1}{B c_{0} \omega^{\frac{1}{2}}}
$$

The plots yield intercepts of $\frac{1}{i_{k}}$, and therefore the kinetic currents, for each potential point. 
That is, extrapolating the current at a theoretical infinite rotation rate removes all restriction from the diffusion limitation and gives a purely kinetic current which is defined by the heterogeneous rate constant for the reaction, $k_{f}$ (forward reaction):

$$
i_{k}=n F A k_{f} C \quad \text { Equation } 2
$$

The potential range for the Koutecky-Levich plots was chosen as it represents the parts of the curve in Figure $3(\mathrm{a}, \mathrm{b})$ where the trend is neither linear nor in the diffusion-limited region, i.e. there is both a kinetic and diffusion contribution to the overall current density. The area of mixed control exists over a relatively large region of overpotential compared to what is typically found in acid electrolyte, meaning Koutecky-Levich analysis is valid for alkaline HOR but not acid HOR [20, 31, 61].

The kinetic currents are then normalised for mass activity (Figure 4a) and specific activity (Figure 4b), in accordance with the method of Garsany et al. [38]. At every potential $\mathrm{Pt} / \mathrm{C}-\mathrm{OH}^{-}$exhibits greater kinetic currents than $\mathrm{Pt} / \mathrm{C}-\mathrm{H}^{+}$. Given the catalyst used in both is the same, this shows that use of acidic ionomer in alkaline RDE studies masks the true activity of the catalyst, which could lead to errors in reporting of catalyst performance.

A Tafel analysis of the kinetic current was also conducted in order to extract the exchange current density $\left(j_{0}\right)$ of the electrodes. The linear region of a plot of log current density vs potential (Figure $4 \mathrm{c}$ ) has a gradient of $\frac{1}{b}=-\frac{\alpha_{i} n F}{2.303 R T}$ and an intercept of $\log j_{0}$ allowing calculation of $j_{0}$ and the charge transfer coefficient $(\alpha)$. Tafel analysis yields $j_{0}$ values of 2.99 and $2.01 \mathrm{~mA} \mathrm{~cm}^{-2}$, and $\alpha n$ values of 0.53 and 0.43 for $\mathrm{Pt} / \mathrm{C}-\mathrm{OH}^{-}$and $\mathrm{Pt} / \mathrm{C}-\mathrm{H}^{+}$, respectively, again highlighting that the use of acidic ionomer gives deceptively low indication of activity. Indeed, given the agglomeration seen in the $\mathrm{Pt} / \mathrm{C}-\mathrm{OH}^{-}$electrodes (Figure 1), the repression of true activity and kinetic performance of catalysts tested using proton conducting ionomer may be even starker than shown in these results. These results do, however, give an indication of the performance in an operating fuel cell environment as they use the commercially available ionomers as constituents of the RDE inks. 
In order to further elucidate the effect of $\mathrm{Nafion}^{\circledR}$ on the apparent electrochemistry of catalysts, EIS was carried out on the electrodes to deconvolute the resistances to charge transfer $\left(R_{C T}\right)$ and diffusion $\left(R_{D}\right)$. The data and equivalent circuit fits are shown in Figure 5a and the fit was obtained using the modified Randles circuit shown in Figure $5 \mathrm{~b}$ and good fits to the data were obtained in both cases. The data in Figure 5a show finite diffusion behaviour, as would be expected for a RDE experiment, and thus the bounded transmissive Warburg element (represented by ' $W$ ') was used in the EIS fit in order to obtain the $R_{D}$ values. Figure $5 \mathrm{c}$ shows the values for $R_{C T}$ (diagonal pattern) and $R_{D}$ (hash pattern) for the $\mathrm{Pt} / \mathrm{C}-\mathrm{OH}^{-}$(black) and $\mathrm{Pt} / \mathrm{C}-\mathrm{H}^{+}$(grey) electrodes. $R_{D}$ is significantly higher for the Nafion ${ }^{\circledR}$ based electrodes due to the higher resistance to diffusion of hydroxide ions through the cationic ionomer than for the anionic exchange ionomer. The $R_{C T}$ values for $\mathrm{Pt} / \mathrm{C}-\mathrm{OH}^{-}$and $\mathrm{Pt} / \mathrm{C}-\mathrm{H}^{+}$are similar, indicating that the poorer performance of the latter catalyst in alkaline electrolyte is mainly due to higher mass transport resistances in the electrode (as would be expected for the commercially prepared catalyst).

Though overall performance of the catalyst is dependent on the total impedance of the whole system, conducting EIS can be a useful diagnostic step to help ascertain the quality of the prepared electrode (affecting $R_{D}$ ) and therefore separate the inherent activity of the catalyst $\left(R_{C T}\right)$ from any systematic or experimental artefacts that might give a lower activity in Tafel analysis. As with all RDE experiments, it is not possible to obtain an activity greater than the actual activity of the catalyst and therefore as much care as possible should be taken to prepare a good quality electrode in a clean cell so as to minimize any effects that mask the true performance of the catalyst. The importance of using an alkaline exchange ionomer binder in place of $\mathrm{Nafion}^{\circledR}$ for alkaline experiments is again highlighted by these data.

\section{Summary}

This study demonstrates, for the first time, that the use of acidic ionomer in electrode preparation for alkaline HOR RDE analysis gives a falsely low estimate of the activity of a commercially available Pt/C electrocatalyst. Though electrode layers can be made without the 
use of an ionomer binder, inclusion of it in the electrode more closely represents the conditions experienced in a fuel cell membrane electrode assembly, and it is therefore recommended in comparative studies of fuel cell electrocatalyst performance. When including an ionomer in the electrode, it is imperative that an alkaline anion exchange ionomer is used for experiments conducted in alkaline electrolytes.

\section{Acknowledgments}

The authors would like to acknowledge the EPSRC for supporting the Electrochemical Innovation Lab through (EP/M009394/1, EP/G030995/1, EP/I037024/1, EP/M014371/1, EP/K014706/1, EP/K038656/1 and EP/M023508/1). PRS acknowledges the Royal Academy of Engineering for funding.

\section{References}

[1] J.R. Varcoe, R.C.T. Slade, E. Lam How Yee, Chemical Communications, (2006).

[2] J.R. Varcoe, R.C.T. Slade, G.L. Wright, Y. Chen, The Journal of Physical Chemistry B, 110 (2006) 21041-21049.

[3] M. Piana, M. Boccia, A. Filpi, E. Flammia, H.A. Miller, M. Orsini, F. Salusti, S. Santiccioli, F. Ciardelli, A. Pucci, Journal of Power Sources, 195 (2010) 5875-5881. [4] K. Fukuta, H. Inoue, Y. Chikashige, H. Yanagi, ECS Meeting Abstracts, 1001 (2010) 275-275.

[5] H. Yanagi, S. Watanabe, K. Sadasue, T. Isomura, H. Inoue, K. Fukuta, ECS Meeting Abstracts, 902 (2009) 341-341.

[6] S. Gu, R. Cai, T. Luo, Z. Chen, M. Sun, Y. Liu, G. He, Y. Yan, Angewandte Chemie International Edition, 48 (2009) 6499-6502.

[7] J.R. Varcoe, R.C.T. Slade, Fuel Cells, 5 (2005) 187-200.

[8] E. Agel, J. Bouet, J.F. Fauvarque, Journal of Power Sources, 101 (2001) 267-274.

[9] B. Xing, O. Savadogo, Electrochemistry Communications, 2 (2000) 697-702.

[10] J.-S. Park, S.-H. Park, S.-D. Yim, Y.-G. Yoon, W.-Y. Lee, C.-S. Kim, Journal of Power Sources, 178 (2008) 620-626.

[11] R. Jervis, D.J.L. Brett, Alkaline Anion Exchange Membrane Fuel Cells, in: Materials for Low-Temperature Fuel Cells, Wiley-VCH Verlag GmbH \& Co. KGaA, 2014, pp. 3-32. [12] R. Jervis, N. Mansor, C. Gibbs, C.A. Murray, C.C. Tang, P.R. Shearing, D.J.L. Brett, Journal of The Electrochemical Society, 161 (2014) F458-F463.

[13] J.R. Varcoe, P. Atanassov, D.R. Dekel, A.M. Herring, M.A. Hickner, P.A. Kohl, A.R. Kucernak, W.E. Mustain, K. Nijmeijer, K. Scott, T. Xu, L. Zhuang, Energy \& Environmental Science, 7 (2014) 3135-3191.

[14] S. Maurya, S.-H. Shin, Y. Kim, S.-H. Moon, Rsc Advances, 5 (2015) 37206-37230.

[15] D.R. Dekel, Journal of Power Sources, (2017). 
[16] S. Maheswari, P. Sridhar, S. Pitchumani, Electrocatal, 3 (2012) 13-21.

[17] S. Lu, J. Pan, A. Huang, L. Zhuang, J. Lu, Proceedings of the National Academy of Sciences of the United States of America, 105 (2008) 20611-20614.

[18] S.D. Poynton, J.P. Kizewski, R.C.T. Slade, J.R. Varcoe, Solid State Ionics, 181 (2010) 219-222.

[19] F.H.B. Lima, J. Zhang, M.H. Shao, K. Sasaki, M.B. Vukmirovic, E.A. Ticianelli, R.R. Adzic, The Journal of Physical Chemistry C, 111 (2006) 404-410.

[20] W. Sheng, H.A. Gasteiger, Y. Shao-Horn, Journal of The Electrochemical Society, 157 (2010) B1529-B1536.

[21] A.J. Appleby, Journal of electroanalytical chemistry and interfacial electrochemistry, 357 (1993) 117-179.

[22] B.B. Blizanac, P.N. Ross, N.M. Marković, The Journal of Physical Chemistry B, 110 (2006) 4735-4741.

[23] J. Kim, A.A. Gewirth, The Journal of Physical Chemistry B, 110 (2006) 2565-2571.

[24] K.J.J. Mayrhofer, D. Strmcnik, B.B. Blizanac, V. Stamenkovic, M. Arenz, N.M.

Markovic, Electrochimica Acta, 53 (2008) 3181-3188.

[25] J. Durst, A. Siebel, C. Simon, F. Hasche, J. Herranz, H.A. Gasteiger, Energy \&

Environmental Science, 7 (2014) 2255-2260.

[26] I. Ledezma-Yanez, W.D.Z. Wallace, P. Sebastián-Pascual, V. Climent, J.M. Feliu, M.T.M. Koper, 2 (2017) 17031.

[27] R. Jervis, N. Mansor, C. Gibbs, C.A. Murray, C.C. Tang, D.J.L. Brett, ECS Transactions, 58 (2013) 637-650.

[28] Y. Garsany, J. Ge, J. St-Pierre, R. Rocheleau, K. Swider-Lyons, ECS Transactions, 58 (2013) 3-14.

[29] T.J. Schmidt, H.A. Gasteiger, G.D. Stab, P.M. Urban, D.M. Kolb, R.J. Behm, Journal of The Electrochemical Society, 145 (1998) 2354-2358.

[30] H.A. Gasteiger, N.M. Markovic, P.N. Ross, The Journal of Physical Chemistry, 99 (1995) 8290-8301.

[31] N.M. Markovica, S.T. Sarraf, H.A. Gasteiger, P.N. Ross, Journal of the Chemical Society, Faraday Transactions, 92 (1996).

[32] S.N. Pronkin, A. Bonnefont, P.S. Ruvinskiy, E.R. Savinova, Electrochimica Acta, 55 (2010) 3312-3323.

[33] D. Santiago, G.G. Rodriguez-Calero, H. Rivera, D.A. Tryk, M.A. Scibioh, C.R. Cabrera, Journal of The Electrochemical Society, 157 (2010) F189-F195.

[34] N.A. Maiorova, A.A. Mikhailova, O.A. Khazova, V.A. Grinberg, Russ J Electrochem, 42 (2006) 331-338.

[35] J. Koutecky, V. Levich, Zh. Fiz. Khim, 32 (1958) 1565-1575.

[36] J. Masa, C. Batchelor-McAuley, W. Schuhmann, R. Compton, Nano Res., 7 (2014) 71-78.

[37] A.J. Bard, L.R. Faulkner, Method Involving Forced Convention--Hydrodynamic Methods, in: Electrochemical Methods: Fundamentals and Applications, Wiley, 2000, pp. 331-367.

[38] Y. Garsany, O.A. Baturina, K.E. Swider-Lyons, S.S. Kocha, Analytical Chemistry, 82 (2010) 6321-6328. 
[39] S.S. Kocha, K. Shinozaki, J.W. Zack, D.J. Myers, N.N. Kariuki, T. Nowicki, V.

Stamenkovic, Y. Kang, D. Li, D. Papageorgopoulos, Electrocatal, 8 (2017) 366-374. [40] A. Suleiman, C.L. Menendez, R. Polanco, E.R. Fachini, Y. Hernandez-Lebron, M.J.F. Guinel, R. Roque-Malherbe, C.R. Cabrera, RSC Advances, 5 (2015) 7637-7646.

[41] Y. Wang, G. Wang, G. Li, B. Huang, J. Pan, Q. Liu, J. Han, L. Xiao, J. Lu, L. Zhuang, Energy \& Environmental Science, 8 (2015) 177-181.

[42] R. Jiang, D. Chu, Journal of Power Sources, 245 (2014) 352-361.

[43] C.A. Hancock, A.L. Ong, P.R. Slater, J.R. Varcoe, Journal of Materials Chemistry A, 2 (2014) 3047-3056.

[44] J. Suntivich, H.A. Gasteiger, N. Yabuuchi, Y. Shao-Horn, Journal of The Electrochemical Society, 157 (2010) B1263-B1268.

[45] J. Suntivich, H.A. Gasteiger, N. Yabuuchi, H. Nakanishi, J.B. Goodenough, Y. Shao-Horn, Nat Chem, 3 (2011) 546-550.

[46] T. Maiyalagan, K. Scott, Journal of Power Sources, 195 (2010) 5246-5251.

[47] L. Demarconnay, C. Coutanceau, J.M. Léger, Electrochimica Acta, 53 (2008) 3232-3241.

[48] L. Demarconnay, C. Coutanceau, J.M. Léger, Electrochimica Acta, 49 (2004) 4513-4521.

[49] H.T. Chung, Y.-K. Choe, U. Martinez, J.H. Dumont, A. Mohanty, C. Bae, I. Matanovic, Y.S. Kim, Journal of The Electrochemical Society, 163 (2016) F1503-F1509.

[50] H.A. Miller, F. Vizza, M. Marelli, A. Zadick, L. Dubau, M. Chatenet, S. Geiger, S. Cherevko, H. Doan, R.K. Pavlicek, S. Mukerjee, D.R. Dekel, Nano Energy, 33 (2017) 293-305.

[51] M.D. Woodroof, J.A. Wittkopf, S. Gu, Y.S. Yan, Electrochemistry Communications, 61 (2015) 57-60.

[52] K. Oda, H. Kato, K. Fukuta, H. Yanagi, ECS Meeting Abstracts, 1001 (2010) 192-192.

[53] M. Vikkisk, I. Kruusenberg, U. Joost, E. Shulga, I. Kink, K. Tammeveski, Applied Catalysis B: Environmental, 147 (2014) 369-376.

[54] S.-D. Yim, H.T. Chung, J. Chlistunoff, D.-S. Kim, C. Fujimoto, T.-H. Yang, Y.S. Kim, Journal of The Electrochemical Society, 162 (2015) F499-F506.

[55] W. Lu, Z.-G. Shao, G. Zhang, Y. Zhao, J. Li, B. Yi, International Journal of Hydrogen Energy, 38 (2013) 9285-9296.

[56] K.J.J. Mayrhofer, G.K.H. Wiberg, M. Arenz, Journal of The Electrochemical Society, 155 (2008) P1-P5.

[57] V.J. Bharath, R. Jervis, J. Millichamp, T.P. Neville, T. Mason, B. Tjaden, P.R. Shearing, R.J.C. Brown, G. Manos, D.J.L. Brett, International Journal of Hydrogen Energy, 42 (2017) 6243-6249.

[58] C.T. Bowen, H.J. Davis, B.F. Henshaw, R. Lachance, R.L. LeRoy, R. Renaud, International Journal of Hydrogen Energy, 9 (1984) 59-66.

[59] A. Pozio, M. De Francesco, A. Cemmi, F. Cardellini, L. Giorgi, Journal of Power Sources, 105 (2002) 13-19.

[60] J. Zhang, PEM Fuel Cell Electrocatalysts and Catalyst Layers: Fundamentals and Applications, Chapter 11, Springer, 2008.

[61] F.J. Vidal-Iglesias, J. Solla-Gullón, V. Montiel, A. Aldaz, Electrochemistry 
Communications, 15 (2012) 42-45.

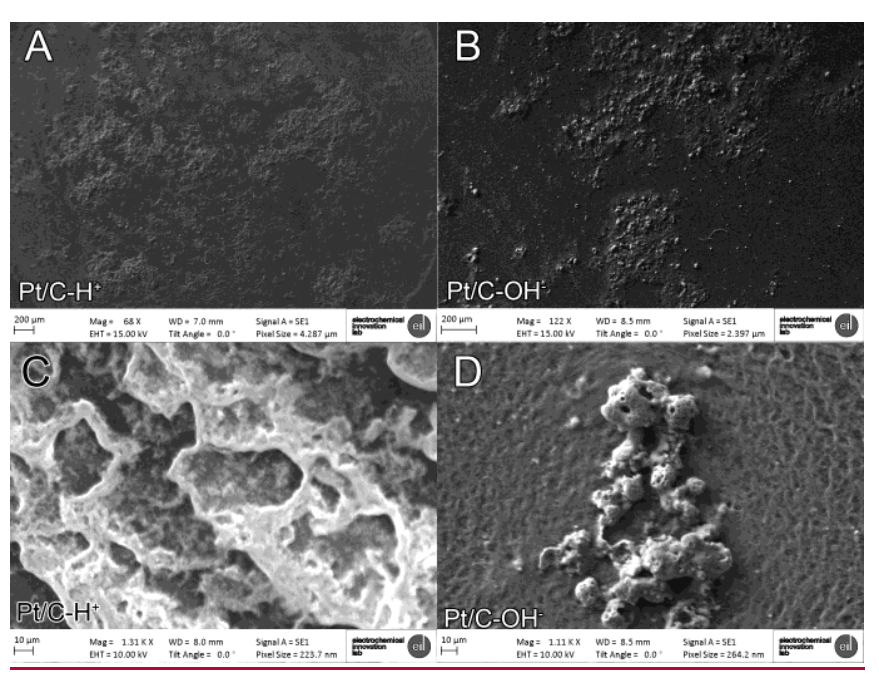

Figure 1 SEM images of the RDE electrode surfaces of the $\mathrm{Pt} / \mathrm{C}-\mathrm{H}^{+}$(a, c) and $\mathrm{Pt} / \mathrm{C}-\mathrm{OH}^{-}$ (b, d) surfaces. 

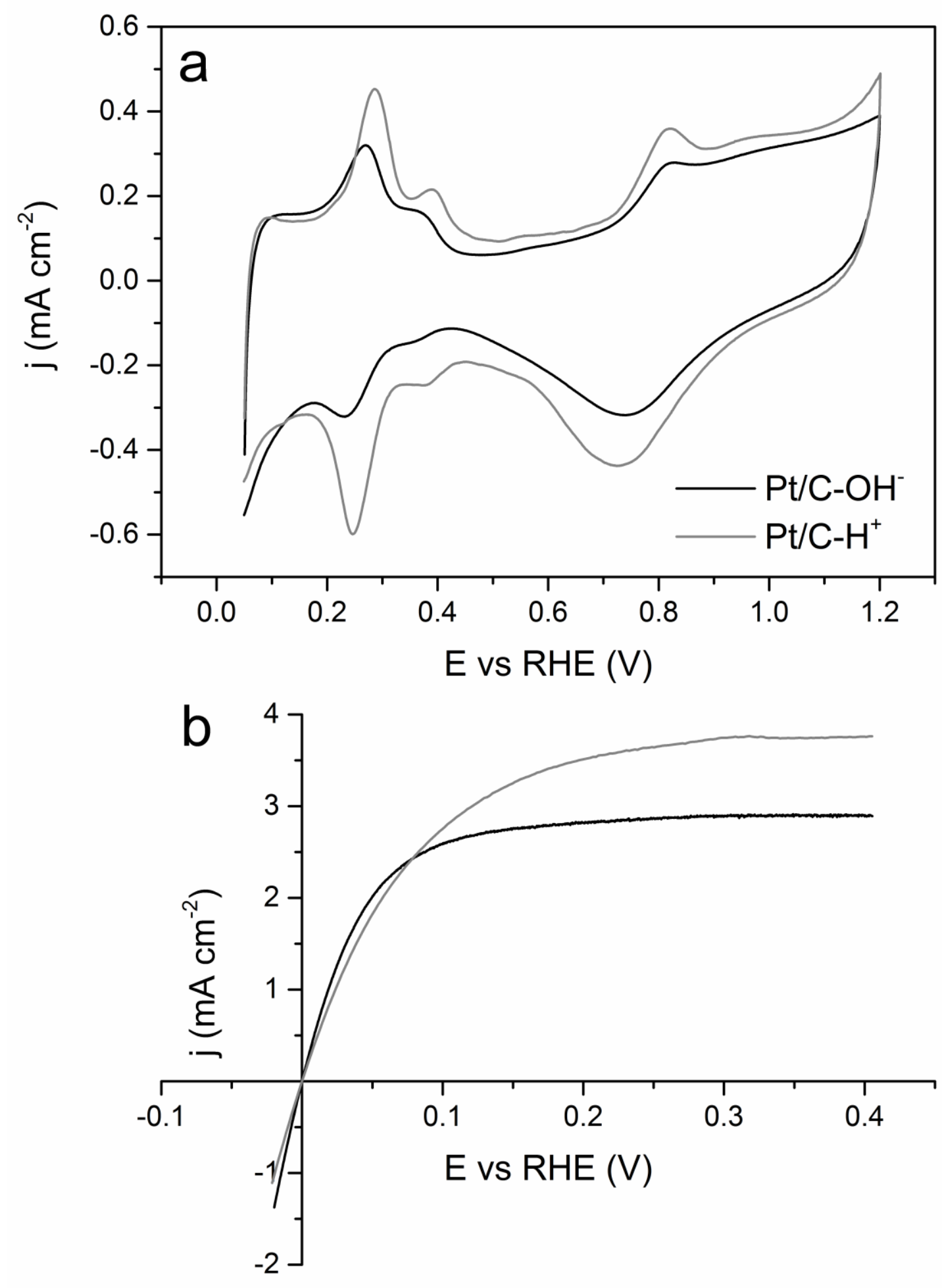

Figure 2 CVs (a) and LSVs (b) of Pt/C-OH- (black) and Pt/C-H $-\mathrm{H}^{+}$(grey) obtained in 0.1 $\mathrm{M} \mathrm{KOH}_{(\mathrm{aq})}$ electrolyte. CV (a) scanned from 0.05-1.2 V vs RHE at $20 \mathrm{mV} \mathrm{s}$ and in deaerated electrolyte with no rotation. LSVs of the HOR (b) were obtained at $5 \mathrm{mV} \mathrm{s}^{-1}$ 
from -0.025-0.4 V vs RHE in $\mathrm{H}_{2}$ (g) saturated electrolyte at $1600 \mathrm{rpm}$.
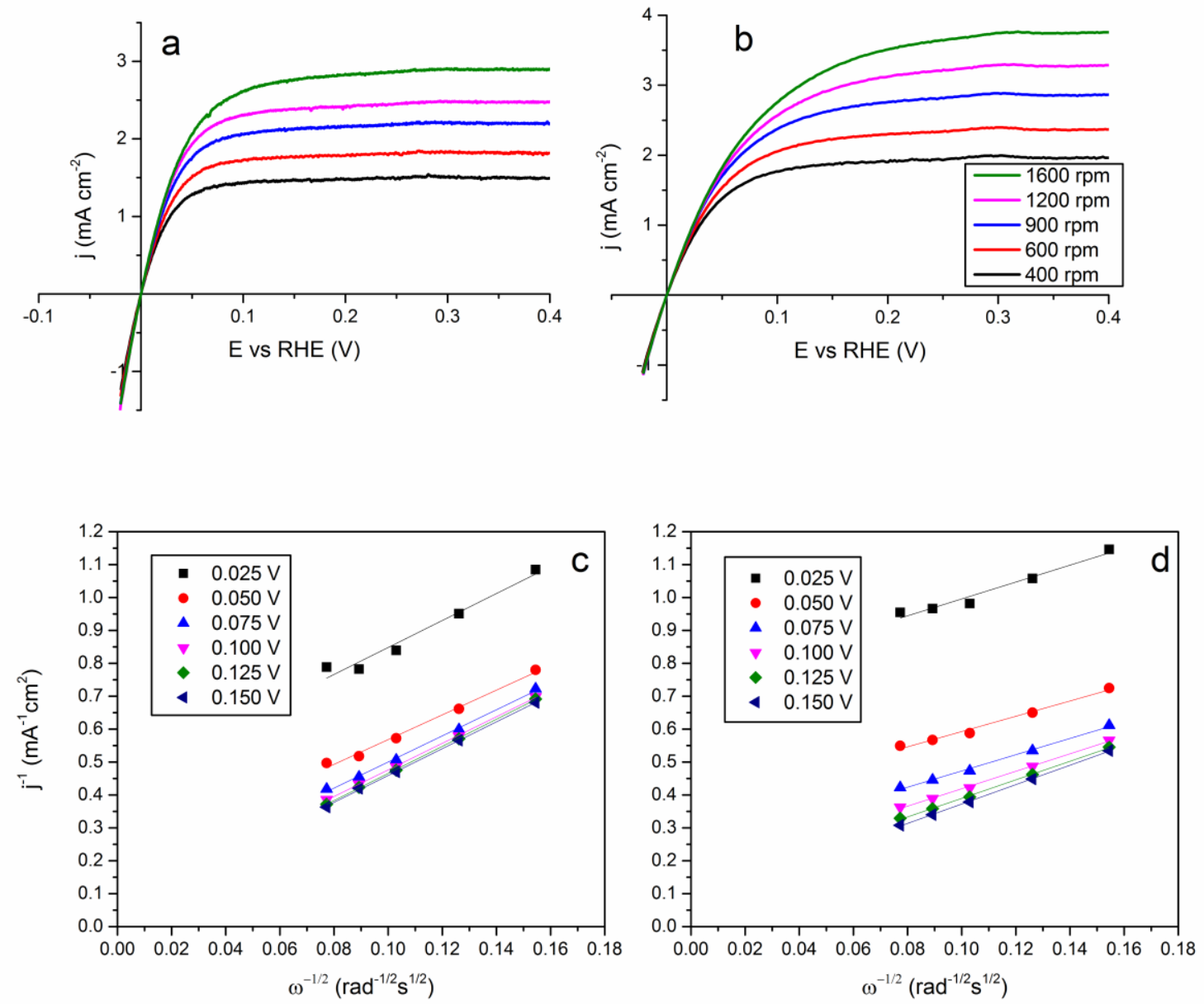

Figure 3 LSVs of the HOR on Pt/C-OH- (a) and Pt/C-H ${ }^{+}$(b) electrodes, obtained at 5 $\mathrm{mV} \mathrm{s}^{-1}$ scan rate from $-0.025-0.4 \mathrm{~V}$ vs RHE in a $\mathrm{H}_{2}$ (g) saturated $0.1 \mathrm{M} \mathrm{KOH}_{(\mathrm{aq})}$ electrolyte at electrode rotation rates $400-1600 \mathrm{rpm}$. Corresponding Koutecky-Levich plots are created from the LSVs in accordance with Equation 1 at five different polarisations between 0.025-0.15 V for $\mathrm{Pt} / \mathrm{C}-\mathrm{OH}^{-}(\mathrm{c})$ and $\mathrm{Pt} / \mathrm{C}-\mathrm{H}^{+}$(d) 

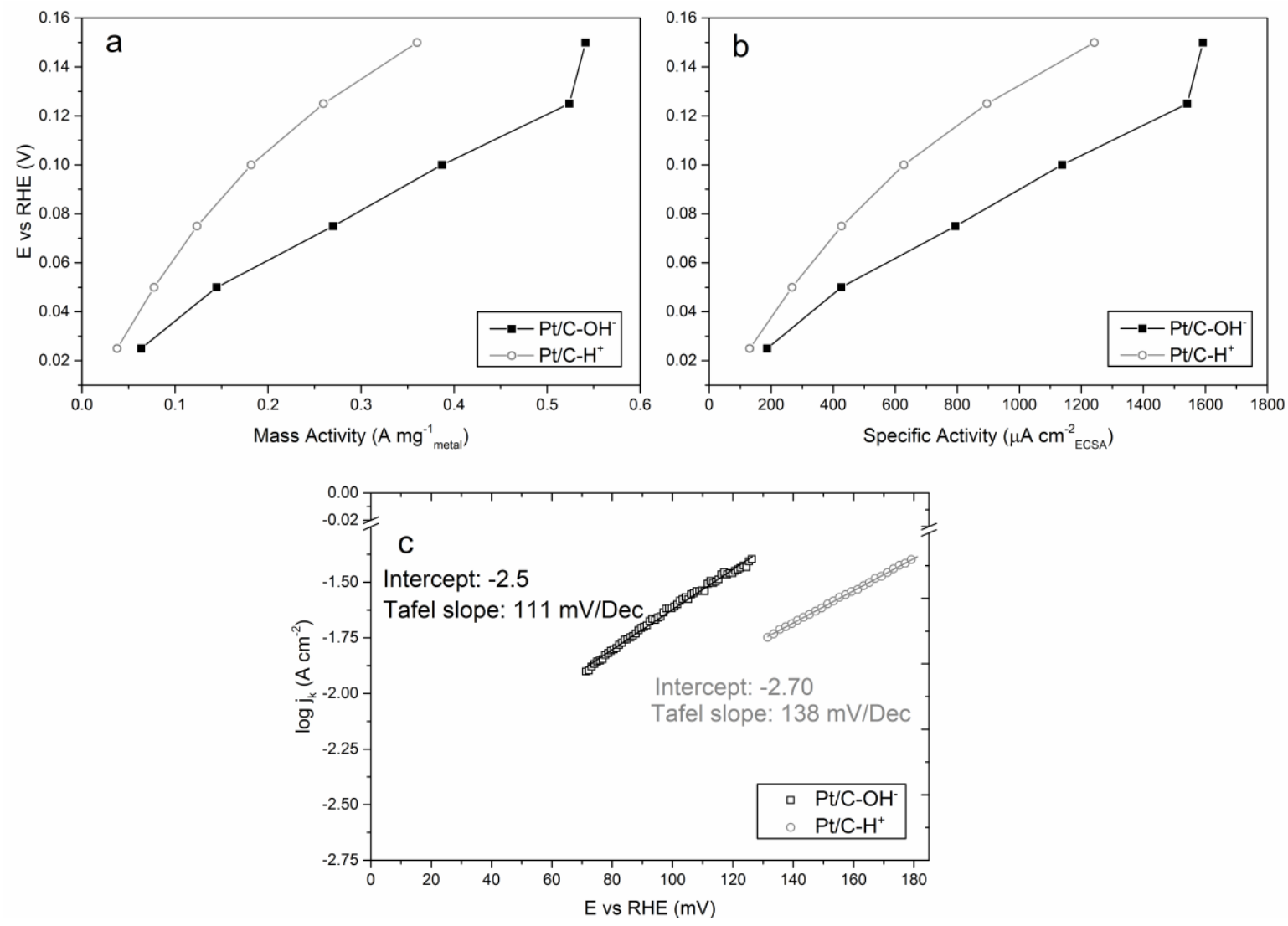

Figure 4 Kinetic currents (extracted from Koutecky-Levich analysis) for $\mathrm{Pt} / \mathrm{C}-\mathrm{OH}^{-}$

(black filled squares) and $\mathrm{Pt} / \mathrm{C}-\mathrm{H}^{+}$(grey hollow circles) electrodes normalised to both the mass loading (a) and ECSA (b) of the catalyst and Tafel plot of kinetic currents (c). 

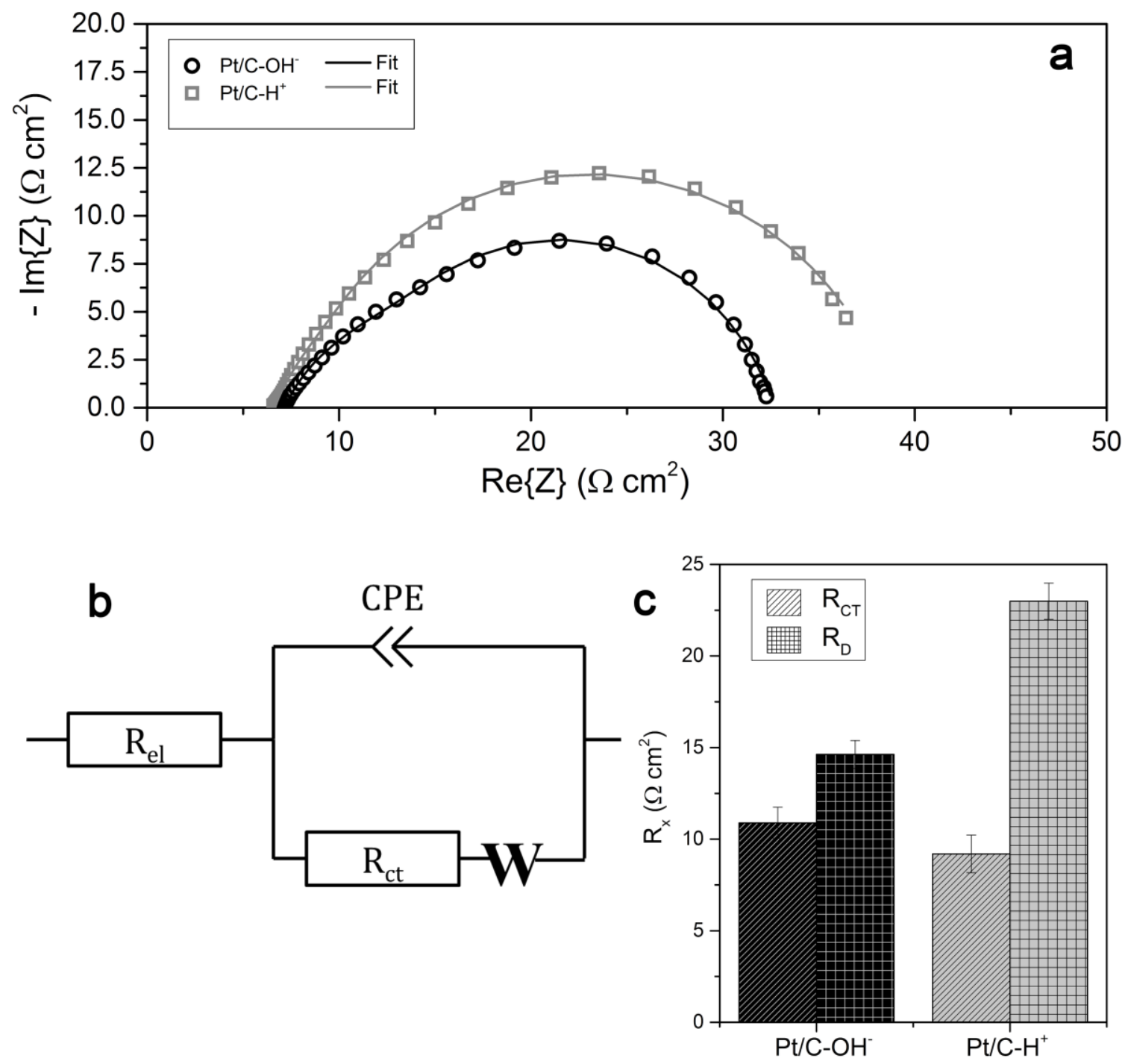

Catalyst

Figure 5. EIS of the two electrodes (a) showing the data for $\mathrm{Pt} / \mathrm{C}-\mathrm{OH}^{-}$(black squares) and $\mathrm{Pt} / \mathrm{C}-\mathrm{H}^{+}$(grey circles) at $0.025 \mathrm{~V}$ vs $\mathrm{RHE}, 1600 \mathrm{rpm}$ rotation rate and in a $\mathrm{H}_{2}$ saturated $0.1 \mathrm{M} \mathrm{KOH}(\mathrm{aq})$ electrolyte, and the equivalent circuit fits (corresponding lines) obtained using a modified Randles circuit (b). Values obtained from the fit are shown (c) for $R_{C T}$ (diagonal pattern) and $R_{D}$ (hash pattern) for the $\mathrm{Pt} / \mathrm{C}-\mathrm{OH}^{-}$(black) and $\mathrm{Pt} / \mathrm{C}-\mathrm{H}^{+}$ (grey) electrodes. 